\title{
Shaft Twist Moment Analysis of Turbocharger ABB Type VTR 354 Due to Surging Phenomenon
}

\author{
Beny Cahyono ${ }^{1}$, Aguk Zuhdi Muhammad Fathallah ${ }^{2}$, Istiqomah ${ }^{3}, \mathrm{Semin}^{4}$ \\ (Received: 07 August 2017 / Revised: 24 June 2019 / Accepted: 29 September 2019)
}

\begin{abstract}
This case is known by excessive sound or vibration in the turbocharger. The main cause of surging phenomenon is divided into two types, that is failure operation by crew and improper selection turbocharger by the designer. This research identifies the effect of surging on twisting moment of turbocharger shaft ABB type VTR 354 on Niigata 8MG40X engine. The method is using simulation based on Finite Element Method (FEM), start from determining the compressor and turbine torque then preparing the turbocharger shaft and simulation with SolidWorks. It is found that critical area caused by surging is located on compressor seat. The largest torque difference at $\mathbf{5 0 \%}$ of the engine load about $\mathbf{- 1 . 3 0 4} \mathbf{~ N m}$ and maximum stress is about $0.015906 \mathrm{Mpa}$, while the displacement is about $0.0000270028 \mathrm{~mm}$ and the maximum strain is about $6.26693 \mathrm{e}-008 \mathrm{~mm} / \mathrm{mm}$. Thus, the shaft material 17NiCrMo6-4 is considered capable of dealing with surging on the turbocharger.
\end{abstract}

Keywords — shaft turbocharger, surging, twist moment.

\section{INTRODUCTION}

$\mathrm{T}$ urbocharger is one of the additional components on a diesel engine. It used to improve engine performance by increase air mass before entering the combustion chamber. With larger air mass, allowing more fuel to burn at the same engine volume, thus more power is generated. The principle work of turbocharger uses exhaust gas from the combustion chamber to drive the turbine wheel before the gases are thrown out. Because the turbine and compressor wheel is connected by the same shaft, thus compressor wheel followed the turbine rotation and it can supply more air from the ambient room.

There are three main components of the turbocharger that is the compressor, shaft, and turbine. First, the compressor in the turbocharger generally refers to the pressure ratio to determine the material selection. Many turbochargers use aluminum alloy as base compressor material that produces less than 4.5 of the pressure ratio, while the pressure ratio more than 4.5 will use titanium material. The second component is the turbocharger shaft that connects between the compressor wheel and the turbine blade. The design of the turbocharger shaft usually refers to the dimension of the turbocharger itself.

Beny Cahyono, Department of Marine Engineering, Institut Teknologi Sepuluh Nopember, Surabaya, 60111, Indonesia. E-mail: cak_beny@yahoo.com

Aguk Zuhdi Muhammad Fathallah, Department of Marine Engineering, Institut Teknologi Sepuluh Nopember, Surabaya, 60111, Indonesia. E-mail: fathalaz@gmail.com

Istiqomah, Departement of Marine Engineering, Institut Teknologi Sepuluh Nopember, Surabaya, 60111, Indonesia. E-mail: istiqmh20@gmail.com

Semin, Department of Marine Engineering, Institut Teknologi Sepuluh Nopember, Surabaya, 60111, Indonesia. E-mail: seminits@yahoo.com
For small dimension, most of them are made separately from the turbine seat. While for larger dimensions, the shaft is made fixed with the turbine, but it can not be used as a reference. The last main component of the turbocharger is a turbine. There are two types of commonly used that is a radial and axial turbine. Radial turbine generally used on the engine with a power range of $500 \mathrm{~kW}$ until $4900 \mathrm{~kW}$. Moreover, the next type is axial turbine that used for low to medium speed engine. This type can provide high efficiency to the power supply on the compressor with a low-pressure ratio condition [1].

The most often cases that happened on the turbocharger is surging. It is a phenomenon that occurs when the air condition after passing the compressor wheel has higher pressure than ambient pressure in the engine room. In other words, if there is less in air pressure carried by the turbocharger, then the higher air pressure in the system will push the air back toward the compressor side. It leads to the emergence of back pressure on the compressor wheel. This impulse causes the turbocharger stopped for a while during operation like stomped. After that, the compressor will re-spin over its normal rotation.

Ship's crew can know easily the indication of surging, such as it produced louder sound and excessive vibration. They usually decrease the engine power until it can be stable to reduce the condition, but as a direct effect, the vessel can not sail with the normal previous operation. Generally, a surging phenomenon can be divided into two large main cause of its occurrence. The first cause is failure operation by the ship's crew. For example when the vessel will enter the port, which initially it sails with certain power and speed, suddenly they drop off the power instantly lowered. It can be caused by surging directly. The other example, such as dirty intercooler, can cause a decrease in air volume after passing it, etc.

Furthermore, the second main cause is wrong selection turbocharger (or called retrofitting) by the 
designer. When selecting turbocharger, the designer should know the characteristic between each engine and turbocharger that will be matched. As an example is a result of retrofitting calculation between Niigata $8 \mathrm{MG} 40 \mathrm{X}$ engine that used existing turbocharger ABB VTR 401 before with turbocharger ABB type VTR 321 and VTR 354 by Soetresno [1]. From two types of the turbocharger that used as candidates, one of them shows that the turbocharger ABB type VTR 354 has operating line located on the surging area. It means that the turbocharger is not matched with the engine.

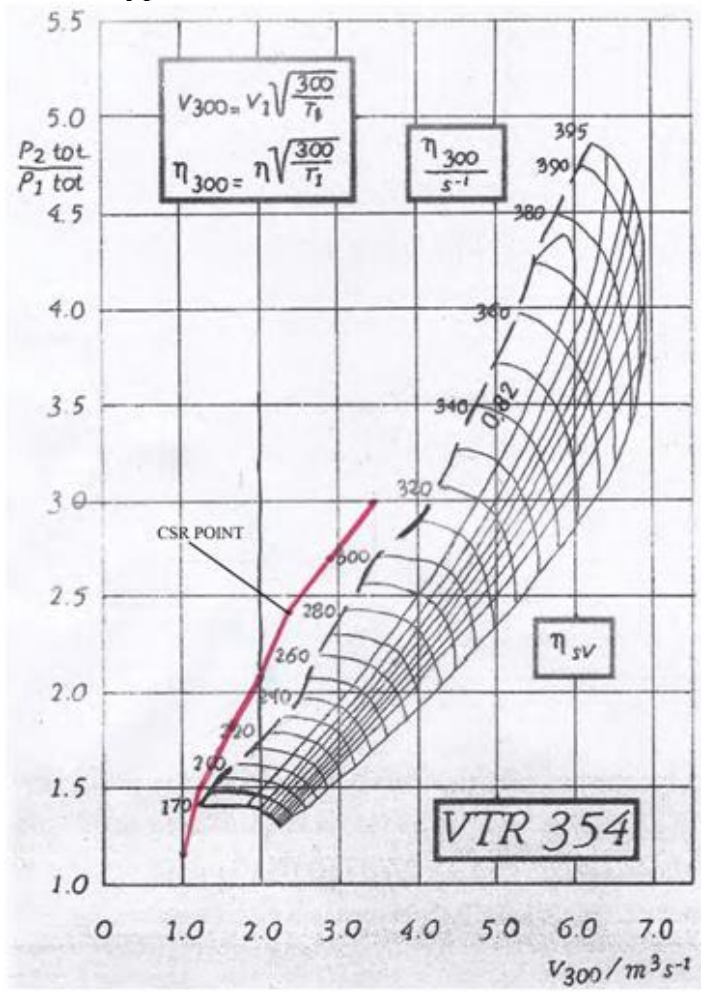

Figure. 1. Operating line of retrofitting calculation on compressor map turbocharger ABB type VTR 354 [1].

In Figure 1, it can be seen the operating line as the result of retrofitting calculation (red line) is located on the left side of the surge line compressor map VTR 354. The line has been made from some load engine (on the chart, only shown load engine from 40 until 100\%). The existing turbocharger has a 2.6 bar of pressure ratio, while the retrofitting turbocharger VTR 354 has a pressure ratio about 3.0 bar. The new one is not matching with the engine caused by some factors. If pressure ratio VTR 354 higher than VTR 401 causes excessive pressure into the system that can directly affect to intake valve. The higher incoming air pressure, it will limit the intake valve opening. The excess air should be limited in the system. In case if still using turbocharger VTR 354, it is necessary to widen the air intake and set the valve. It needs to check the intake valve before installing the turbocharger onto the engine because it is possible that surging can occurs due to some amount of the gas escapes from compression.

When the surging phenomenon often occurs on the turbocharger, it is feared will have an impact on its main components. For example, some cases reported that the turbocharger shaft was broken. There are several reasons that allow the case to occur. Maybe the material had been fatigue, or it gave large twist moment thus these shafts run into a torque. Another possible reason is jammed oil supply to the bearing system. This research discusses the surging phenomenon affect to the twisting moment of turbocharger shaft VTR 354 using FEM simulation.

\section{METHOD}

This research using secondary data from Soetresno's research [1] that discuss retrofitting between Niigata 8MG40X engine with turbocharger ABB type 321 and VTR 354. Actually, these engine using turbocharger VTR 401. Because some data about surging is needed in this research, thus the result of retrofitting turbocharger VTR 354 is taken. Some required data is shown in Table 1 and Table 2. Furthermore for turbocharger VTR 354, the needed data such as general specification (Table 3 ), data of turbocharger performance for torque calculation (Table 4), and shaft turbocharger dimension (Figure 2 and Table 5) for modeling on FEM software and the material properties of the shaft. 
International Journal of Marine Engineering Innovation and Research, Vol. 4(3), Sept. 2019. 155-163 (pISSN: 2541-5972, eISSN: 2548-1479)

TABLE 1.

MAIN PARTICULAR OF SHIP

\begin{tabular}{|c|c|}
\hline \multicolumn{2}{|c|}{ MIAIN PAR TICULAR OF SHIP } \\
\hline Ship's Name & Kirana II \\
\hline Type & Ferry Ro-Ro \\
\hline Length of Overall (Loa) & $109 \mathrm{~m}$ \\
\hline Length (Lpp) & $100 \mathrm{~m}$ \\
\hline Breadth (B) & $17.4 \mathrm{~m}$ \\
\hline Depth $(\mathrm{H})$ & $6.26 \mathrm{~m}$ \\
\hline Draft $(\mathrm{T})$ & $4.15 \mathrm{~m}$ \\
\hline Classification & BKI \\
\hline Flag State & Indonesia \\
\hline Place of Manufacture & Narasaki Shipbuilding, Japan \\
\hline Year of Manufacture & 1989 \\
\hline \multicolumn{2}{|c|}{$\begin{array}{c}\text { TABLE } 2 . \\
\text { SPECIFICATION OF MAIN ENGINE [1] }\end{array}$} \\
\hline Merk & Niigata \\
\hline Type & $8 \mathrm{MG} 40 \mathrm{X}$ \\
\hline Number of Cylinder & 8 Cylinders \\
\hline Bore & $400 \mathrm{~mm}$ \\
\hline Stroke & $520 \mathrm{~mm}$ \\
\hline Maximum Power & $2600 \mathrm{HP}$ \\
\hline Maximum Speed & $340 \mathrm{rpm}$ \\
\hline
\end{tabular}

Several calculations are needed to calculate the compressor or turbine torque. At the beginning is the calculation of compressor efficiency $\left(\eta_{c}\right)$ (Eq.1) [2]. Where $\pi_{c}$ is the compressor pressure ratio, $T_{\text {in }}$ is the inlet compressor $\left({ }^{\circ} \mathrm{K}\right)$, and $\mathrm{k}$ is 1.325 .

$$
\eta_{c}=\frac{\pi_{c}^{(\mathrm{k}-1) / \mathrm{k}-1}}{\mathrm{~T}_{\text {out }} / \mathrm{T}_{\text {in }}-1}
$$
air temperature $\left({ }^{\circ} \mathrm{K}\right), \mathrm{T}_{\text {out }}$ is the air temperature after

TABLE 3.

SPECIFICATION OF TURBOCHARGER ABB VTR 354 [1]

\begin{tabular}{ll}
\hline Merk & ABB \\
Type & VTR 354 \\
Specification & GB6NT29, 6-IVMA211 W14Z3 \\
Speed & $18900 \mathrm{rpm}$ \\
Pressure Ratio & $3 \mathrm{bar}$
\end{tabular}

Then, determining the compressor power value, with following Eq.2 [2]. Where $\mathrm{P}_{c}$ is the compressor power $(\mathrm{kW}), \dot{\mathrm{m}}_{a}$ is the air mass flow rate $(\mathrm{kg} / \mathrm{s})$, and $\mathrm{C}_{p}$ is
$1.01737 \mathrm{~kJ} / \mathrm{kg}^{\circ} \mathrm{K}$.

$\mathrm{P}_{c}=\frac{\dot{\mathrm{m}}_{a} \mathrm{C}_{p} \mathrm{~T}_{i n}\left(\pi_{c}^{(\mathrm{k}-1) / \mathrm{k}}-1\right)}{\eta_{c}}$ 
International Journal of Marine Engineering Innovation and Research, Vol. 4(3), Sept. 2019. 155-163 (pISSN: 2541-5972, eISSN: 2548-1479)

Finally, the value of compressor torque can be calculated by Eq.3 [2]. Where $\tau_{c}$ is compressor torque

$$
\tau_{c}=\frac{\mathrm{P}_{c}}{2 \pi \times \mathrm{n}}
$$
$(\mathrm{Nm})$ and $\mathrm{n}$ is the rotation of the turbocharger $(\mathrm{rpm})$.

TABLE 4.

TURBOCHARGER VTR 354 PERFORMANCE [1]

\begin{tabular}{cccccc}
\hline $\begin{array}{c}\text { Engine } \\
\mathbf{L}(\boldsymbol{\%})\end{array}$ & $\boldsymbol{\pi}_{\mathbf{c}}$ & $\begin{array}{c}\mathbf{T}_{\mathbf{i n}} \\
(\mathbf{K})\end{array}$ & $\begin{array}{c}\mathbf{T}_{\text {out }} \\
(\mathbf{K})\end{array}$ & $\begin{array}{c}\dot{\mathbf{m}}_{\mathbf{a}} \\
\mathbf{( k g} / \mathbf{s})\end{array}$ & $\begin{array}{c}\mathbf{n} \\
(\mathbf{r p m})\end{array}$ \\
\hline 10 & 0.3 & 318 & 193.69 & 0.0061 & - \\
20 & 0.6 & 318 & 257.67 & 0.0203 & - \\
30 & 0.9 & 318 & 304.49 & 0.0428 & - \\
40 & 1.2 & 318 & 342.79 & 0.0726 & - \\
50 & 1.5 & 318 & 375.78 & 0.1166 & 11040 \\
60 & 1.8 & 318 & 405.07 & 0.1746 & 13800 \\
\hline 70 & 2.1 & 318 & 431.62 & 0.2469 & 15420 \\
80 & 2.4 & 318 & 456.02 & 0.3367 & 17100 \\
90 & 2.7 & 318 & 478.68 & 0.4537 & 17940 \\
100 & 3 & 318 & 499.90 & 0.5952 & 18960 \\
\hline
\end{tabular}

Moreover, for determining the turbine torque is firstly completes the formula of mechanical efficiency of the shaft turbocharger and turbine power [3]. The Eq. 4 is the calculation for the mechanical efficiency $\eta_{m}$. Where $\mathrm{P}_{f b}$ is the bearing friction power $(\mathrm{kW})$ and $\mathrm{P}_{t}$ is turbine power $(\mathrm{kW})$.

$\eta_{m}=1-\frac{\mathrm{P}_{f b}}{\mathrm{P}_{t}}$

In case, the bearing friction power $\left(\mathrm{P}_{f b}\right)$ using the Eq.5. The $\tau_{f b}$ is bearing friction torque (Nmm), which the value is derived from Figure 3 with assumption take the "measurement" trend line.
$\mathrm{P}_{f b}=1.05 \times 10^{-4} \times \tau_{f b} \times \mathrm{n}$

The turbine power calculation is taken from the compressor power value multiplied with mechanical efficiency [3].

$\mathrm{P}_{t}=\eta_{m} \times \mathrm{P}_{c}$

Then the value of turbine torque $\left(\tau_{t}\right)$ can be calculated using the following equation (Eq. 7).

$\tau_{t}=\frac{\mathrm{P}_{t}}{2 \pi \mathrm{xn}}$

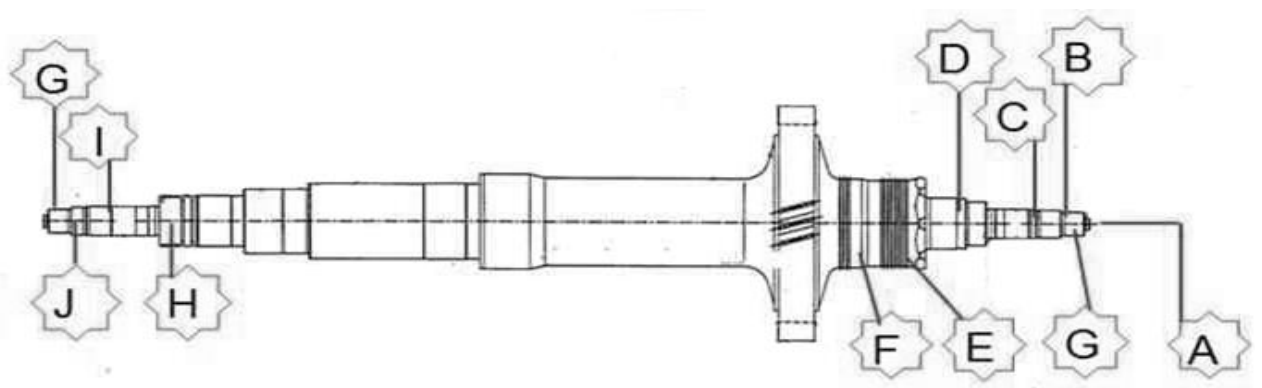

Figure. 2. Shaft turbocharger ABB type VTR 354 Model 
International Journal of Marine Engineering Innovation and Research, Vol. 4(3), Sept. 2019. 155-163 (pISSN: 2541-5972, eISSN: 2548-1479)

TABLE 5

DIMENSION OF SHAFT TURBOCHARGER OF FIGURE 2

\begin{tabular}{|c|c|c|}
\hline Code & Part & Diameter (mm) \\
\hline A & Pump Spigot & - \\
\hline $\mathrm{B}$ & Centrifuge Seat Turbine Side & 31.006 \\
\hline $\mathrm{C} 1$ & $\begin{array}{l}\text { Bearing Journal Turbine } \\
\text { Side } 1\end{array}$ & 31.837 \\
\hline $\mathrm{C} 2$ & $\begin{array}{l}\text { Bearing Journal Turbine } \\
\text { Side } 2\end{array}$ & 32.037 \\
\hline $\mathrm{C} 3$ & $\begin{array}{l}\text { Bearing Journal Turbine } \\
\text { Side } 3\end{array}$ & 32.237 \\
\hline $\mathrm{D}$ & Sealing Bush Turbine Side & 55.50 \\
\hline $\mathrm{E}$ & Sealing Strip 1 & 99.40 \\
\hline F & Sealing Strip 2 & 102.40 \\
\hline G & $\begin{array}{l}\text { Shaft End Tread } \\
\text { Turbine/Compressor Side }\end{array}$ & - \\
\hline $\mathrm{H}$ & $\begin{array}{l}\text { Sealing Bush Compressor } \\
\text { Side }\end{array}$ & 79.45 \\
\hline I1 & $\begin{array}{l}\text { Bearing Journal Compressor } \\
\text { Side } 1\end{array}$ & 31.837 \\
\hline $\mathrm{I} 2$ & $\begin{array}{l}\text { Bearing Journal Compressor } \\
\text { Side } 2\end{array}$ & 32.037 \\
\hline I3 & $\begin{array}{l}\text { Bearing Journal Compressor } \\
\text { Side } 3\end{array}$ & 32.237 \\
\hline $\mathrm{J}$ & $\begin{array}{l}\text { Centrifuge Seat Compressor } \\
\text { Side }\end{array}$ & 31.006 \\
\hline
\end{tabular}

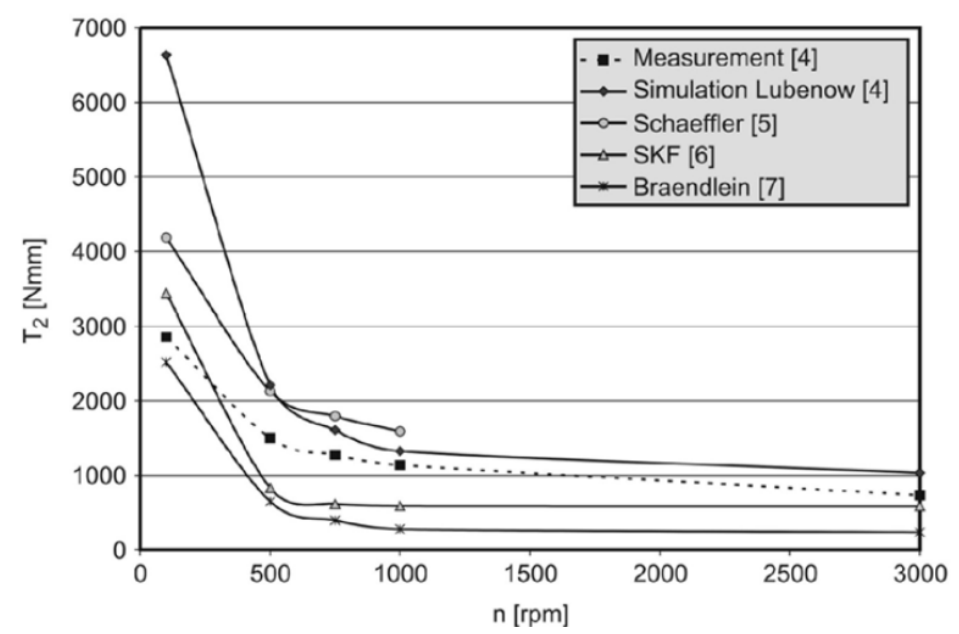

Figure 3. Graph for determine bearing friction torque [4]

\section{RESULTS AND DISCUSSION}

According to the calculation before, the result of the torque calculation is in Table 6 and Table 7. Then, it has been calculated the difference torque between compressor and turbine for torque value (Table 8). Thus, the $\Delta \tau$ can be obtained that shows the magnitude of the torsion value given to simulation. 
TABLE 6.

COMPRESSOR TORQUE AT EACH ENGINE LOAD

\begin{tabular}{|c|c|c|c|c|c|c|}
\hline $\begin{array}{c}\text { Load } \\
(\%)\end{array}$ & $\pi_{\mathrm{c}}$ & $\boldsymbol{\eta}_{\mathbf{c}}$ & $\begin{array}{c}\dot{\mathbf{m}}_{\mathbf{a}} \\
(\mathrm{kg} / \mathrm{s})\end{array}$ & $\begin{array}{c}\mathbf{P}_{\mathbf{c}} \\
(\mathbf{k W})\end{array}$ & $\begin{array}{c}\mathbf{n} \\
(\mathbf{r p m})\end{array}$ & $\begin{array}{c}\tau_{\mathbf{c}} \\
(\mathrm{Nm})\end{array}$ \\
\hline 10 & 0.3 & 0.73 & 0.0061 & 0.77 & - & - \\
\hline 20 & 0.6 & 0.70 & 0.0203 & 1.25 & - & - \\
\hline 30 & 0.9 & 0.69 & 0.0428 & 0.58 & - & - \\
\hline 40 & 1.2 & 0.67 & 0.0726 & -1.83 & - & - \\
\hline 50 & 1.5 & 0.66 & 0.1166 & -6.85 & 11040 & -5.93 \\
\hline 60 & 1.8 & 0.66 & 0.1746 & -15.47 & 13800 & -10.71 \\
\hline 70 & 2.1 & 0.65 & 0.2469 & -28.55 & 15420 & -17.69 \\
\hline 80 & 2.4 & 0.64 & 0.3367 & -47.28 & 17100 & -26.42 \\
\hline 90 & 2.7 & 0.64 & 0.4537 & -74.18 & 17940 & -39.51 \\
\hline 100 & 3 & 0.63 & 0.5952 & -110.15 & 18960 & -55.51 \\
\hline
\end{tabular}

Furthermore, the value of $\Delta \tau$ becomes input data to FEM simulation. Some simulation to do such as stress, amount of displacement, strain and safety factor. The result (Figure 4) at 50\% of the engine load is an example from several engine load variations $(50 \%, 60 \%, 70 \%$, $80 \%, 90 \%$ and $100 \%$ ). It is found that the minimum value is at the end of compressor side one with the value about $6.94279 \times 10^{-12} \mathrm{Mpa}$, while the maximum value is $0.015906 \mathrm{Mpa}$. The result is still far from the stress limit of material used (17NiCrMo6-4) that is about 295.594 Mpa. It means that the turbocharger shaft material is stronger than the load given.
Another result of some loads is about $0.015296 \mathrm{Mpa}$ at $60 \%$ of the engine load, $0.015052 \mathrm{Mpa}$ at $70 \%$ of the engine load, $0.014808 \mathrm{Mpa}$ at $80 \%$ of the engine load, $0.014686 \mathrm{Mpa}$ at $90 \%$ of the engine load and 0.014076 Mpa at $100 \%$ of the engine load. An object moving from one point to another point caused by a given certain force. It is different between one end with another end called displacement because the forces that work on the turbine is considered $0 \mathrm{Nm}$ but on the compressor side there is still has some value that works and it bigger than $0 \mathrm{Nm}$. Thus, it leads to a twisting moment.

TABLE 7.

TURBINE TORQUE AT EACH ENGINE LOAD

\begin{tabular}{|c|c|c|c|c|c|}
\hline $\begin{array}{c}\text { Load } \\
(\%)\end{array}$ & $\eta_{\mathbf{m}}$ & $\begin{array}{c}\mathbf{P}_{\mathbf{c}} \\
(\mathbf{k W})\end{array}$ & $\begin{array}{c}\mathbf{P}_{\mathbf{t}} \\
(\mathbf{k W})\end{array}$ & $\begin{array}{c}\mathbf{n} \\
(\mathbf{r p m}) \\
\end{array}$ & $\begin{array}{c}\tau_{\mathrm{t}} \\
(\mathbf{N m}) \\
\end{array}$ \\
\hline 10 & 0.80 & 0.77 & 0.97 & - & - \\
\hline 20 & 0.80 & 1.25 & 1.45 & - & - \\
\hline 30 & 0.80 & 0.58 & 0.78 & - & - \\
\hline 40 & 0.80 & -1.83 & -1.63 & - & - \\
\hline 50 & 0.80 & -6.85 & -6.65 & 11040 & -4.63 \\
\hline 60 & 0.80 & -15.47 & -15.27 & 13800 & -9.46 \\
\hline 70 & 0.79 & -28.55 & -28.35 & 15420 & -16.45 \\
\hline 80 & 0.80 & -47.28 & -47.08 & 17100 & -25.20 \\
\hline 90 & 0.79 & -74.18 & -73.98 & 17940 & -38.30 \\
\hline 100 & 0.79 & -110.15 & -109.95 & 18960 & -54.35 \\
\hline
\end{tabular}

As an example, the result of displacement simulation at $50 \%$ of the engine load is in Figure 5. The largest displacement is obtained about $2.70028 \times 10^{-5} \mathrm{~mm}$. Another displacement result of some loads are $2.59675 \mathrm{x}$ 
$10^{-5} \mathrm{~mm}$ at $60 \%$ of the engine load, $2.55532 \times 10^{-5} \mathrm{~mm}$ load and $2.38966 \times 10^{-5} \mathrm{~mm}$ at $100 \%$ of the engine load. at $70 \%$ of the engine load, $2.51391 \times 10^{-5} \mathrm{~mm}$ at $80 \%$ of the engine load, $2.4932 \times 10^{-5} \mathrm{~mm}$ at $90 \%$ of the engine

TABLE 8.

TORQUE DIFFERENCES BETWEEN THE COMPRESSOR AND TURBINE

\begin{tabular}{cccc}
\hline \multicolumn{4}{c}{ TORQUE DIFFERENCES BETWEEN THE COMPRESSOR AND TURBINE } \\
\hline 10 & $\boldsymbol{\tau}_{\mathbf{c}}$ & $\boldsymbol{\tau}_{\mathbf{t}}$ & $\boldsymbol{\Delta} \boldsymbol{\tau}$ \\
\hline 20 & - & - & - \\
30 & - & - & - \\
40 & - & - & - \\
50 & - & - & - \\
60 & -5.93 & -4.63 & -1.30 \\
70 & -10.71 & -9.46 & -1.25 \\
80 & -17.69 & -16.45 & -1.23 \\
90 & -26.42 & -25.20 & -1.21 \\
100 & -39.51 & -38.30 & -1.20 \\
\hline
\end{tabular}

The strain is closely related to pulling of an object. The greater value of the strain will increasingly stretch the object and opposite. From the simulation result obtained that the maximum strain is located on the compressor seat as same as stress area with the value equal to $6.26693 \times 10^{-8}$ and it is at $50 \%$ of the engine load (Figure 6). Another strain result of some loads are $6.02663 \times 10^{-8}$ at $60 \%$ of the engine load, $5.93051 \times 10^{-8}$ at $70 \%$ of the engine load, $5.8344 \times 10^{-8}$ at $80 \%$ of the engine load, $5.78634 \times 10^{-8}$ at $90 \%$ of the engine load and $5.54604 \times 10^{-8}$ at full load.

Moreover, at the critical stress areas (Figure 7), it shows the twist moment load of the most dominant stress on the shaft between the turbine and compressor seat also some areas of the compressor seat. The most critical area shown by the red color that lies at the end of the compressor seat. Nevertheless, the displacement critical areas (Figure 8) that occur on the turbocharger shaft with the same load more indicates close to another one end of the compressor seat. It is due to the throwing force as the function of the length of the shaft.

Same as the critical areas of stress, the strain (Figure 9) results also indicate the most potentially highest strain is located on the shaft between the turbine and compressor seat. Also, the areas could be potentially located on the right end of the compressor seat. While for the safety of factor (Figure 10), indicates that the entire area of the turbocharger shaft is a critical area. It can be said that this shaft has a good design for loads beyond its normal operations. If there is an excessive force this shaft can distribute the force to other parts of the shaft thus it becomes equal. However, on the shaft end area close to the turbine side indicates uneven loads. It may be caused by improper bearing treads.

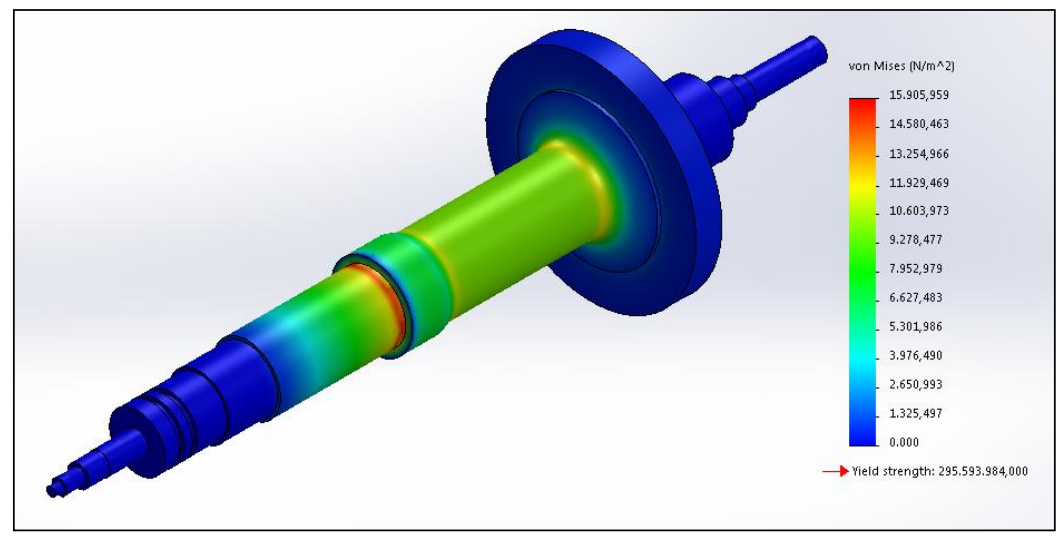

Figure. 4. Stress at $50 \%$ of the engine load 
International Journal of Marine Engineering Innovation and Research, Vol. 4(3), Sept. 2019. 155-163 (pISSN: 2541-5972, eISSN: 2548-1479)

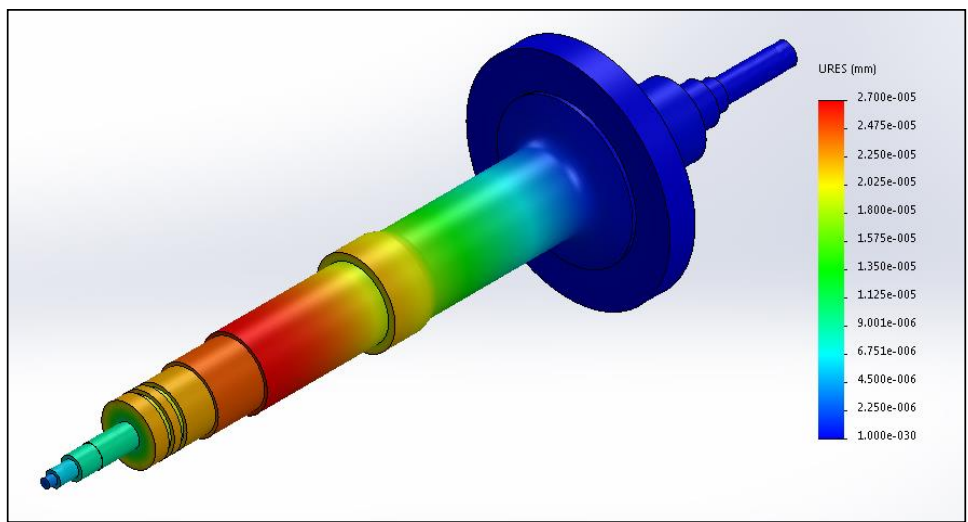

Figure. 5. Displacement at 50\% of the engine load

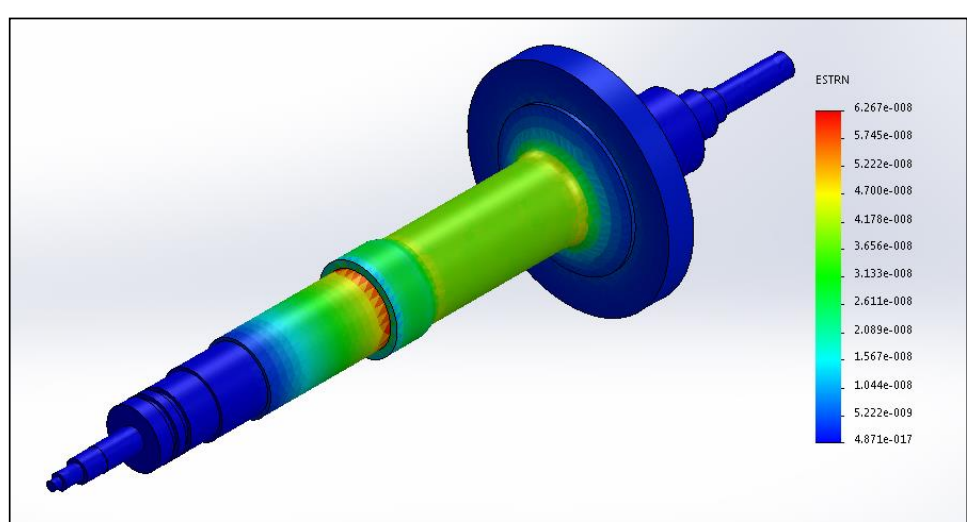

Figure. 6. Strain at $50 \%$ of the engine load

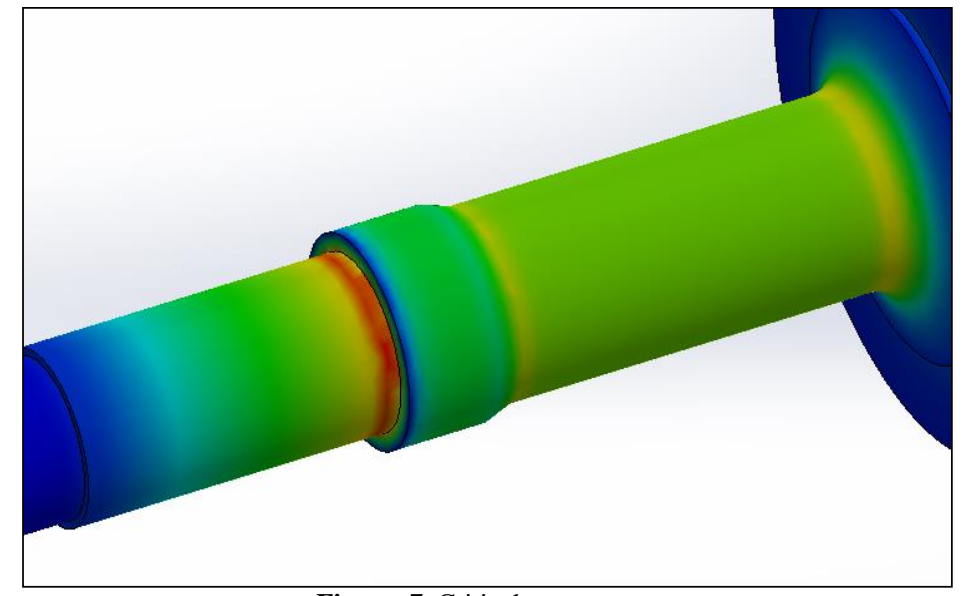

Figure. 7. Critical stress areas

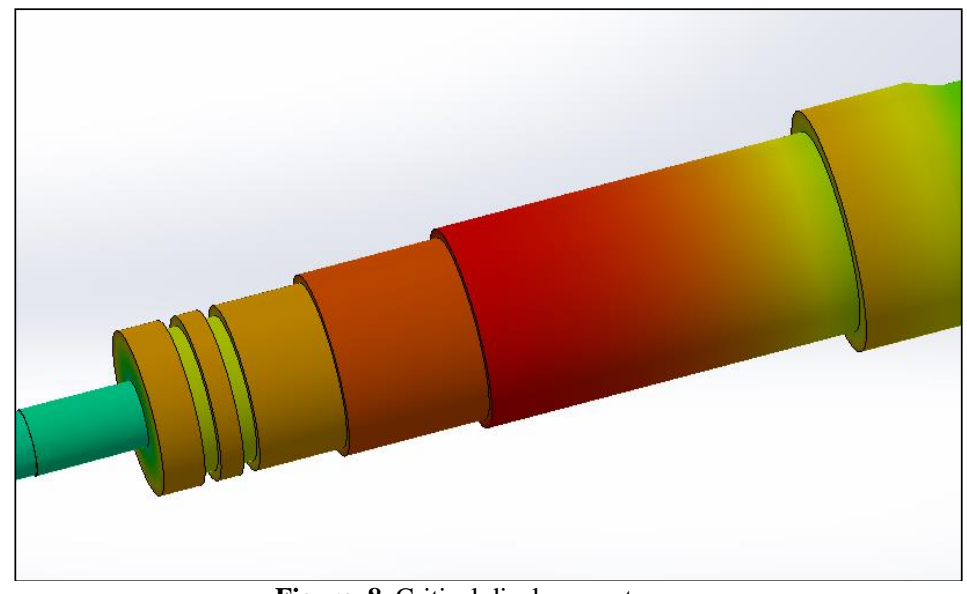

Figure. 8. Critical displacement areas 


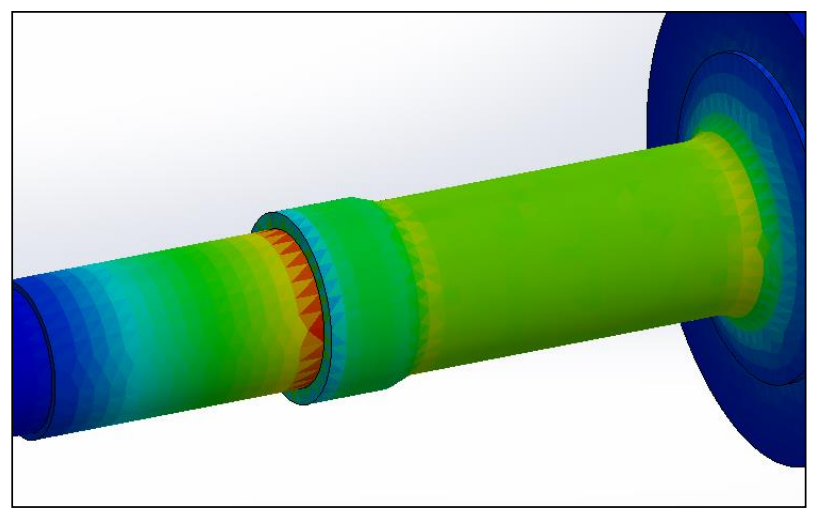

Figure 9. Critical strain areas

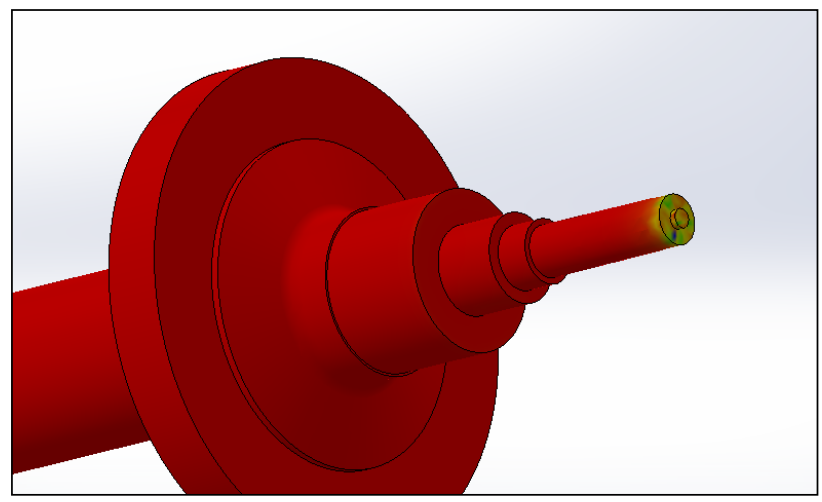

Figure 10. The critical areas of safety factor

\section{CONCLUSION}

Based on data analysis and simulation result using FEM, it can be concluded that :

1) The more increasing load engine causes the compressor and turbine torque increased too, but the difference between both torques will be decreased.

2) From some simulations, the largest torsion differences at $50 \%$ of the engine load with the value is about $-1.304 \mathrm{Nm}$. Maximum stress is about $0.015906 \mathrm{Mpa}$, while the displacement of the shaft occurs very small amount is about $2.70028 \times 10^{-5} \mathrm{~mm}$ and the maximum strain is $6.26693 \times 10^{-8}$. It means the torque is still lower than the material limits of the turbocharger shaft (17NiCrMo6-4) which is $295.594 \mathrm{Mpa}$.

3) The critical area of stress and strain is almost the same that is located at one end of the compressor seat. While displacement indicates the critical area at the other end of compressor seat. Different from the safety factor, its critical areas almost appear on all parts of the shaft, therefore the loads obtained can be distributed equally.

\section{REFERENCES}

[1] Soetresno, "Analisa Turbocharger Engine Matching pada Proses Retrofitting Engine Niigata 8MG40X dengan Turbocharger Merk BBC Type VTR 401," Skripsi: Jurusan Teknik Sistem Perkapalan, Fakultas Teknologi Kelautan, Institut Teknologi Sepuluh Nopember Surabaya, 2015.

[2] L. C. R. Lilly, "Diesel Engine Reference Book," UK: Butterwhorts \& Co, Ltd, 1984.

[3] H. Nguyen-Schäfer, "Rotordynamics of Automotive Turbochargers," Springer International Publishers, 2015.

[4] S. Söndgen and W. Predki, "Power Loss and Axial Load Carrying Capacity of Radial Cylindrical Roller Bearings," American Gear Manufacturers Association, 2013. 